Kamilla Dolińska

ORCID: https://orcid.org/0000-0002-0505-4732

Instytut Socjologii Uniwersytetu Wrocławskiego

Justyna Kajta

ORCID: https://orcid.org/0000-0002-2428-8876

Instytut Nauk Społecznych, SWPS Uniwersytet Humanistycznospołeczny

Julita Makaro

ORCID: https://orcid.org/0000-0002-2589-0519

Instytut Socjologii Uniwersytetu Wrocławskiego

Natalia Niedźwiecka-Iwańczak

ORCID: https://orcid.org/0000-0002-7894-3274

Instytut Socjologii Uniwersytetu Wrocławskiego

Elżbieta Opiłowska

ORCID: https://orcid.org/0000-0001-7084-2631

Instytut Socjologii Uniwersytetu Wrocławskiego

\title{
Miasta podzielone i pogranicza w studiach socjologicznych - o wyzwaniach i kierunkach badawczych $^{1}$
}

\section{Divided cities and borderlands in sociological studies: challenges and research trends}

\footnotetext{
1 Artykuł powstał w ramach realizacji projektu badawczego „(De/Re)Konstruowanie granic - narracje i imaginacje o miastach podzielonych w Europie Środkowej w perspektywie porównawczej” finansowanego ze środków Narodowego Centrum Nauki w ramach konkursu OPUS, umowa nr UMO-2018/29/B/ HS6/00258.
} 


\begin{abstract}
In recent years, borders have become the focus of attention of researchers from many disciplines and a focal point of public discourse. The optimistic vision of a borderless world which was propagated after the fall of the Iron Curtain turned out to be an illusion. The migration crisis, Brexit or the coronavirus pandemic have demonstrated that borders are still an important instrument of state policy. The aim of this article is to reflect on new trends in the sociology of borderland, in particular on the use of the concepts of narratives in urban studies. The article is the result of the workshop "Narratives and imaginaries of divided cities: between the urban sociology and the sociology of borderland" held on 15-16 October 2020 at the Centre for Regional and Borderlands Studies at the Institute of Sociology, University of Wrocław. The article presents a synthesis of the most important conclusions from the proceedings, while also discussing new research trends and challenges related to the analysis of borderlands and divided cities located.
\end{abstract}

Keywords: divided towns, borders, borderlands, narratives

W ostatnich latach granice znalazły się w centrum zainteresowania zarówno badaczy wielu dyscyplin, jak i opinii publicznej. Propagowana po upadku „żelaznej kurtyny” optymistyczna wizja świata bez granic okazała się iluzją. Kryzys migracyjny, brexit czy pandemia koronawirusa pokazały, że granice wciąż są ważnym instrumentem polityki państwa. Celem niniejszego artykułu jest próba refleksji nad nowymi trendami w socjologii pogranicza, w szczególności nad wykorzystaniem koncepcji narracji w studiach miejskich. Artykuł jest wynikiem warsztatów „Narracje i imaginacje w miastach podzielonych: między socjologią miasta a socjologią pogranicza”, które odbyły się w dniach 15-16 października 2020 r. w Ośrodku Badań Regionalnych i Obszarów Pogranicza w Instytucie Socjologii Uniwersytetu Wrocławskiego. Tekst przedstawia syntezę najważniejszych wniosków z obrad, a jednocześnie omawia nowe kierunki badań i wyzwania związane $\mathrm{z}$ analizą pograniczy i zlokalizowanych $\mathrm{w}$ nich miast podzielonych.

Słowa kluczowe: miasta podzielone, granice, pogranicza, narracje

Odebrano / Received: 30.03.2021

Zaakceptowano / Accepted: 05.10.2021

\title{
Wstęp
}

Granice i pogranicza cieszą się od kilku dekad dużym zainteresowaniem badaczy i badaczek różnych dyscyplin - geografii społecznej, politologii, antropologii czy socjologii. W polskiej socjologii powstała nawet subdyscyplina - socjologia pogranicza (Kurcz 2020), która skupia się na przestrzeni pograniczy i zachodzących tam procesach społecznych.

The current article was prepared within the framework of the research project “(De/Re)Konstruowanie granic - narracje i imaginacje o miastach podzielonych w Europie Środkowej w perspektywie porównawczej” ("(De/Re)Constructing borders - narratives and imaginaries on divided towns in Central Europe in comparative perspective") financed from the National Science Centre funds as part of the OPUS contest, contract no. UMO-2018/29/B/HS6/00258. 
Pogranicze jest przestrzenią kształtowaną przez wielu aktorów społecznych na licznych poziomach - jednostki, które w codziennych sytuacjach bezpośrednio doświadczają pogranicza, instytucjonalne podmioty, które tworzą struktury funkcjonowania pograniczy oraz globalne dyskursy o „świecie bez granic” czy też „europejskiej fortecy”. Narracje i imaginacje związane $z$ granicami ulegają ciągłym przemianom, redefinicjom i często są odpowiedzią na wydarzenia geopolityczne. Kiedy upadła „żelazna kurtyna”, a państwa Europy Środkowej i Wschodniej weszły na drogę demokracji, granice postrzegano przede wszystkim w ujęciu funkcjonalnym jako bariery dla swobodnego przepływu ludzi, kapitału, towarów i usług. Wzrost globalnych powiązań między państwami, gospodarkami i społeczeństwami na świecie spowodował, że imaginacje „świata bez granic” (Ohmae 2008) i kosmopolitycznej Europy (Beck i Grande 2006) na dobre zagościły w dyskursie publicznym. Te określenia nie oznaczały jednakże zniesienia granic czy upadku państw narodowych, ale były raczej luźną metaforą rodzącej się gospodarki neoliberalnej (Paasi 2009). Światowy turysta od zawsze miał swoje alter ego, jak pisał Zygmunt Bauman - włóczęgę (Bauman 1996), przed którym świat nie stał otworem, którego nikt nie witał, a raczej próbował unikać, odgradzając się granicami.

Atak na World Trade Center w 2001 roku jeszcze bardziej wzmocnił działania odgraniczania się $\mathrm{w}$ imię bezpieczeństwa. Powróciły kontrole graniczne, tym razem $\mathrm{w}$ bardziej wyrafinowanych formach - kontroli biometrycznych czy śledzenia ludzi na podstawie wielkich danych (big data). Kryzys gospodarczy, a potem tzw. kryzys uchodźczy utrwaliły imaginację o granicach jako barierach - chroniących przed terrorystami czy też migrantami. Ostatnim wydarzeniem, które sprawiło, że granice stały się jednym z głównych tematów debaty publicznej, był wybuch pandemii koronawirusa w 2020 roku. I choć, jak podkreślają eksperci, wirus nie zna granic, to wiele państw zdecydowało się na wprowadzenie tymczasowego ograniczenia swobody podróżowania jako skutecznej metody przeciwdziałania rozprzestrzenianiu się Covid-19.

Studia nad granicami i pograniczami nie pozostają obojętne wobec tych wydarzeń i zmieniających się narracji. Badacze i badaczki uważnie śledzą nowe reakcje społeczeństw i prognozują wpływ, jaki pandemia będzie miała na wykładnię granic (Dolińska i Makaro 2020; Opiłowska 2021; Wille i Weber 2020).

Zespół Ośrodka Badań Regionalnych i Obszarów Pogranicza (OBROP) w Instytucie Socjologii Uniwersytetu Wrocławskiego, który od 2019 roku realizuje projekt badawczy w ramach konkursu NCN OPUS „(De/Re)Konstruowanie granic narracje i imaginacje o miastach podzielonych w Europie Środkowej w perspektywie porównawczej”² również aktywnie włącza się w najnowsze dyskusje dotyczące granic i pograniczy. W 2020 roku wydaliśmy - w wersji drukowanej oraz cyfrowej - Studia nad granicami i pograniczami. Leksykon, którego celem było stworzenie syntetycznego opracowania mapy haseł dotyczących kwestii teoretyczno-metodologicznych oraz

\footnotetext{
${ }^{2}$ Więcej o projekcie znajduje się na poświęconej mu stronie internetowej: https://granice.uni.wroc.pl/.
} 
kluczowych zjawisk zachodzących na pograniczach europejskich. Tego typu publikacja nie była dotąd opracowana w języku polskim, choć podobne inicjatywy możemy odnaleźć w zachodniej Europie (Gerst i in. 2021; Wassenberger i Reitel 2020, Wilson i Donnan 2012).

Celem podjęcia dyskusji nad nowymi trendami w socjologii pogranicza, ale w szczególności nad wykorzystaniem koncepcji narracji w studiach miejskich, w dniach 15-16 października 2020 roku zorganizowaliśmy warsztaty „Narracje i imaginacje w miastach podzielonych: między socjologią miasta a socjologią pogranicza”. Do udziału w nich zaprosiliśmy badaczki i badaczy zajmujących się problematyką miejską, pogranicza oraz konceptualizacją narracji. Niniejszy artykuł jest próbą syntetycznego przedstawienia najważniejszych wniosków $\mathrm{z}$ naszych obrad, a jednocześnie nakreślenia kierunków badań i wyzwań związanych $\mathrm{z}$ analizą pograniczy i zlokalizowanych w nich miast.

\section{Pogranicza w teorii i empirii}

Granice i pogranicza są przedmiotem wzmożonych interdyscyplinarnych dociekań, co niesie za sobą istotne konsekwencje - konieczność dookreślenia obszaru badawczego i doprecyzowania terminologii. Niestety, wciąż jeszcze brakuje zgody co do zakresu znaczeniowego podstawowej kategorii, jaką jest pogranicze, a także relacji pomiędzy nią a kategoriami pokrewnymi („przygranicze”, „transgranicze”). W ramach refleksji nad pograniczem uwypuklają się trzy kwestie, które trzeba rozstrzygnąć. Po pierwsze, pojawia się tutaj dylemat czy pogranicze jest fenomenem terytorialnym, przestrzennym czy można je ujmować metaforycznie - przykładowo jako pogranicze w człowieku. Po drugie, czy wymaga ono uwzględnienia granicy państwowej i jej względnej bliskości. Po trzecie, czy pogranicze może istnieć (i być interesujące dla socjologa) bez brania pod uwage jego społecznego substratu, wchodzących w relacje społeczno-kulturowe ludzi, różniących się swymi etnicznymi odniesieniami (Niedźwiecka-Iwańczak 2020). Można uznać, że dla większości (polskich) socjolożek i socjologów bezdyskusyjne jest założenie o terytorialności pogranicza, jak również położenie nacisku na jego społeczny aspekt - międzykulturowe kontakty społeczne i to, co w ich konsekwencji się konstytuuje, co wyznacza swoistość pograniczy w zestawieniu z nie-pograniczami, a co ujmowane być może jako efekt pogranicza. Ową specyfikę upatrywać można także w wielości praktyk ogniskujących się wokół granic - społeczno-kulturowych i politycznych, które składają się na rzeczywistość społeczności pogranicza. Zarysowane stanowisko, na polskim gruncie mające już prawie trzydziestoletnią tradycję, zdaje się przyjmować podobną perspektywę w zestawieniu $\mathrm{z}$ kompleksowym podejściem do granic, rozwijanym w nowszych zachodnich koncepcjach - borderescapes lub refleksją nad takimi procesami, jak bordering, ordering, othering (van Houtum i van Naerssen 2002). Novum, którego dotąd brakowało w polskiej socjologii pogranicza, stanowi polityczne zaangażowanie - rozpoznawanie procesów inkluzji i ekskluzji w ich etycznym oraz 
normatywnym aspekcie zawierające się $\mathrm{w}$ koncepcji krajobrazów przygranicznych (Brambilla 2015). Postulat wykorzystywania efektów badań na potrzeby funkcjonowania pogranicza może być dość istotny także dla polskich badaczy, na co wskazywał w trakcie warsztatu Maciej Kowalewski, mówiąc o możliwościach uzupełnienia aktywności badawczej o praktyki wpisujące się w zakres socjologii publicznej.

Wychodząc od międzykulturowych kontaktów społecznych osadzonych przestrzennie, kluczowe w kontekście dalszych decyzji badawczych jest podjęcie zagadnienia delimitacji pogranicza. Jest to kolejna kwestia, która w ramach socjologii pogranicza nie doczekała się do tej pory satysfakcjonującego rozwiązania (Raczyk 2020). Wrocławski zespół przedmiotem swych zainteresowań badawczych uczynił miasta podzielone (Cieszyn-Czeski Cieszyn i Słubice-Frankfurt n. Odrą), w których procesy z granicami „w tle” przyjmują szczególną intensywność, co zyskało w literaturze przedmiotu swoje potwierdzenie (Dolińska i in. 2018). Jerzy Kaczmarek i Łukasz Rogowski, biorący udział w projekcie „DE-RE-BORD. Socio-spatial transformations in German-Polish interstices” obok badania mieszkańców Frankfurtu (Oder), Słubic, wiosek Późnej i Griessen uwzględnili w swej próbie osoby zamieszkujące Poznań i Berlin, przyjmując kategorię „poszerzonej granicy” i zakładając, że obszar jej oddziaływania jest znacznie szerszy niż tylko tereny z nią bezpośrednio sąsiadujące. Rozwiązania przyjęte w obydwu projektach unaoczniają wciąż istniejący w obrębie subdyscypliny problem $z$ rozpatrywaniem pogranicza i jego zasięgu - jak daleko dostrzec możemy przepływy i powiązania ponadgraniczne, a to znajduje swój wyraz także w wykorzystywaniu kategorii przestrzeni powiązań (Verflechtungsraum).

Popularność oraz rozwój studiów nad granicami i pograniczami, których wskaźnikiem jest $\mathrm{z}$ pewnością bogactwo literatury przedmiotu (ujęć teoretycznych i egzemplifikacji empirycznych) stanowić może przesłankę do naszkicowania mapy badań nad pograniczem. Ewentualne wykonanie takiej mapy jest jednak narażone na ryzyko niedokładności, a zarazem i niespójności. Pierwszy problem, jaki się tutaj pojawia, jest ściśle związany z rozwojem refleksji teoretycznej i powiązanych z nim odmienności pojęciowych umożliwiających analizowanie i opisywanie specyfiki rzeczywistości (po)granicznej. Rzecz dotyczy - co podnosiła Kamilla Dolińska - interdyscyplinarności refleksji nad granicami i pograniczami, zmian paradygmatów w myśleniu o nich (od modernistycznego, przez konstruktywistyczny, po postmodernistyczny), kontekstu społeczno-kulturowego warunkującego treści w jej ramach podejmowane oraz języka opisu.

Nawet gdyby tworzyć mapę badań wyłącznie w odniesieniu do polskich pograniczy byłaby ona niedoskonała nie tylko z uwagi na brak spójności pojęciowej, ale i z uwagi na podejmowane przez badaczy decyzje metodologiczne (o których nierzadko nic nie wiemy z racji braku/niepełnych not metodologicznych w publikacjach). Różnorodność przedsięwzięć badawczych nie jest powiązana wyłącznie $z$ wyborem określonego paradygmatu, skłaniającego do stosowania odmiennych metod i technik badawczych, w konsekwencji sposobów opowiadania o pogranicznej rzeczywistości. To również wynik 
decyzji związanych między innymi z (a) konceptualizacją kluczowych kategorii, niepozwalających udzielić jednoznacznej odpowiedzi na pytania „czym jest pogranicze?”, ,jak daleko sięga pogranicze?”, (b) z ustaleniem sposobu doboru próby z uwagi na cechy mające (z założenia) znaczenie przy orzekaniu o specyfice pogranicza, ale nierzadko też ze względu na dostępność określonej kategorii badanych, a także, (c) z rozstrzygnięciem, w jakim czasie pogranicze poddawane było empirycznemu oglądowi. Zasygnalizowane wybrane aspekty różnorodności metodologicznej uniemożliwiają spełnienie warunku istotnego dla konstrukcji potencjalnej mapy - ekwiwalentności porównań w zakresie pomiaru, jednostek obserwacji, punktów w czasie (Słomczyński 2014). W ramy problemu z nieporównywalnymi pomiarami wchodzi również zakres dostępnych badaczowi danych wtórnych „po dwóch stronach” granicy, między innymi sposób ich agregowania, kompletność - na co, w odniesieniu do pary miast podzielonych Cieszyn-Czeski Cieszyn oraz Słubice-Frankfurt nad Odrą, zwracali uwagę Julita Makaro i Marcin Dębicki. To jednocześnie kolejny sygnał wskazujący na trudności stworzenia mapy badań realizowanych „na pograniczach” dyscyplin, paradygmatów, tradycji teoretycznych i kontekstów społeczno-kulturowych.

\section{Badania miast pogranicza}

Analizując miasta podzielone (Makaro 2020), badacze stają przed wyzwaniem odpowiedzenia na pytanie, „na ile obserwowane procesy dają się zrozumieć i wyjaśnić na gruncie już istniejących teorii wypracowanych przez socjologię miasta”, a tym samym, jakie są możliwości „odseparowania czynników determinujących procesy i zjawiska społeczne w miarę powszechnych, uniwersalnych ujawniających się w każdym miejskim układzie osadniczym [...], a co jest konsekwencją przygraniczności tych miast" (Kłopot 2019: 126). W związku $\mathrm{z}$ tym, porównując pary miast podzielonych, uwaga badawcza powinna kierować się zarówno w stronę ich własności przygranicznych (oddziaływanie centrum-peryferia; asymetrie ekonomiczne pomiędzy krajami; relacje pomiędzy władzami na różnych poziomach: lokalne-centralne, lokalne-lokalne i centralne-centralne; historia i pamięć; zróżnicowanie etniczne) i miejskich, choć wyzwanie stanowi orzekanie o rozłączności obu tych kategorii.

Idea porównywania miast podzielonych wynika $z$ dwóch potrzeb. Po pierwsze ustalenia, czy dwie pary miast o różnej historii, położone na różnych pograniczach (a zatem istniejące w odmiennych kontekstach historycznych, politycznych i społecznych) są bytami porównywalnymi, posiadającymi wspólny rdzeń (inny niż tylko historia podziału jednego organizmu miejskiego), upoważniający do ich zestawiania. Po drugie, dokonane porównanie może wyposażyć badacza w wiedzę, która pozwoli wyodrębnić fenomeny mogące pełnić funkcje zmiennych wyjaśniających, uniwersalnych dla wielu przypadków. Przyjmując te założenia rozstrzygnąć należy, w jakich obszarach dokonywać porównań, jakie cechy uwzględnić w charakterystykach miast, by móc powiedzieć, że stanowią one dane, które pozwolą zrozumieć kształt narracji o miastach podzielonych. 
Wybierając zmienne mające stanowić fundament charakterystyki miast, poszukiwaliśmy tych, które można by powiązać $\mathrm{z}$ immanentnie miejskimi walorami oraz te, które wiążą się z ich pogranicznością. Jak wspominał Krzysztof Bierwiaczonek, definicje miasta nakazywałyby skupienie się na cechach układów osadniczych, które charakteryzuje wewnętrzne zróżnicowanie, obecność Innych/Obcych, ale również tworzenie więzi. Porównując wybrane miasta $\mathrm{w}$ ramach naszego projektu, postanowiliśmy się skupić na dostępnych danych charakteryzujących ich potencjał ludnościowy, poszukiwaliśmy również danych pozwalających opisać kapitał społeczny i kulturowy mieszkańców - tu szczególnie dało się odczuć, że badacze są raczej skazani na dostępne informacje, niż mogą sami określać potrzebne wskaźniki: różna wielkość miast oraz ich ulokowanie w trzech państwach sprawia, że dane nie są dostępne dla wszystkich czterech miast, a to przekłada się na trudność budowania wniosków uogólniających.

Miejskość i pograniczność miast podzielonych uchwycona w danych i pozwalająca je opisać (ta pierwsza bardziej - ale nie wyłącznie - dotyczy czterech miast, ta druga par miast) jest problematyczna dla badaczy podobnie jak miejskość i pograniczność traktowana jako cecha zjawisk wyjaśnianych i wyjaśniających, która pozwala je zrozumieć. Przywołany przez Radosława Zenderowskiego casus pomnika słupa granicznego, postawionego przy głównej ulicy Czeskiego Cieszyna w setną rocznicę jego powstania (która jest jednocześnie rocznicą podziału Cieszyna) jest interesującym dla badacza wskaźnikiem budowanej narracji. $Z$ jednej strony można powiedzieć, że samo świętowanie rocznicy i jego forma (słup graniczny zdaje się być kwintesencją ciągłego podtrzymywania komunikatu o przebiegu granicy) jest opowieścią reborderyzacyjną - za sprawą postawienia pomnika odnowiona (symbolicznie) została granica między Cieszynami, ale $\mathrm{z}$ drugiej strony jego znaczenie - gdy porzucić perspektywę transgraniczną - może być fundamentalne dla nadal trwającego procesu budowania tożsamości mieszkańców czeskiego miasta oraz relacji między zamieszkującą je polską mniejszością i czeską większością.

Zdaniem Krzysztofa Bierwiaczonka, badania miast, w tym tych przygranicznych, mogą koncentrować się też na takich aspektach, jak tożsamość miasta i mieszkańców; granice społeczno-kulturowe konstruowane w mieście i wiążące się z pojęciami swojskości i obcości, mających czasami swoje przestrzenne odpowiedniki (np. osiedla grodzone); przestrzeń publiczna i jej społeczne znaczenia oraz narracje miejskie. Skupiając uwagę badawczą na narracjach miejskich, ważne jest dookreślenie aktorów społecznych, którzy mówią w mieście i o mieście. W związku z tym istotne jest dostrzeżenie, że nie ma jednej miejskiej narracji, a to, jakie one będą, zależne jest między innymi od pozycji zajmowanej przez daną osobę lub instytucję w strukturze społecznej miasta. Narracje tworzone przez różnych aktorów mogą się uzupełniać, zderzać, jak i wykluczać nawzajem, a uchwycenie tego zróżnicowania narracyjnego stanowi jeden z celów badawczych. Jak wiadomo z innych badań miast (Bierwiaczonek i in. 2017), opowieści o mieście konstruowane odgórnie mogą być bardziej lub mniej ukierunkowane, zakorzenione 
w przeszłości lub narzucające konkretną narrację dotyczącą przyszłości. Dużą rolę odgrywa tutaj historia i to, jakie różni aktorzy i instytucje mają pomysły na jej opowiedzenie. Odwołując się do przykładu współcześnie tworzonych muzeów, Piotr Kulas zwraca uwagę na to, jak ważna jest ta narracyjność opowiadanej historii i jak odmienne interpretacje przeszłości mogą ze sobą konkurować w ich przypadku. Zgadzając się z tezą, że wykorzystując narracje indywidualne można empirycznie zbliżać się do tożsamości jednostkowej, należy mieć jednocześnie na uwadze, że rozszerzenie kategorii narracji na inne - niż jednostka - podmioty „opowiadające” o społecznej rzeczywistości może przynieść rezultaty pozwalające powiązać te opowieści z kontekstem społecznym, w którym są wytwarzane. Ponadto interesujące są również tematyczne opowieści o codziennych doświadczeniach w określonej przestrzeni.

Jednym z pytań, przed jakim stają badaczki i badacze zajmujący się narracjami w mieście, a jakie zadaje między innymi Maciej Kowalewski, jest to o transformację narracji publicznej w prywatną? W jaki sposób wielkie wydarzenia albo ich lokalne manifestacje przekładają się na praktykowanie miasta, jak i obszaru pogranicza? W jaki sposób to, co pojawia się na poziomie opowieści generowanych przez elity lokalne staje się częścią społecznej świadomości? Czy można takie przejście zbadać? Wydaje się, że nie można udzielić jasnej odpowiedzi na ostatnie z pytań i nie jesteśmy w stanie - jako badacze - uchwycić procesu inkorporowania treści pojawiających się w narracjach publicznych w te prywatne. Podobnie nie jesteśmy w stanie pokazać, w jaki sposób narracje prywatne włączane są w publiczne. To, co jesteśmy w stanie zrobić, to zestawiać te różne poziomy narracji i porównywać je zarówno w zestawach prywatne-prywatne, prywatne-publiczne oraz publiczne-publiczne. W ten sposób możemy zaprezentować to, co jest dla nich wspólne, jak i to, co je odróżnia.

Inną kwestią rozpalającą socjologiczne rozważania jest nie tylko rozstrzyganie, co badać, ale również,jak to można czynić, a jak należy.Jerzy Kaczmarek i Łukasz Rogowski, charakteryzując metodologię badań w projekcie „DE-RE-BORD”, wskazali na wykorzystanie takich procedur badawczych, jak między innymi wideo spacery, rejestrowanie danych przez aplikację służącą geolokalizacji respondentów i tym samym identyfikowanie ich codziennych praktyk. Co ważne, żadna z tych metodologii nie została wykorzystana jako samodzielne źródło danych, a raczej dopełnienie tradycyjnego rzemiosła socjologicznego - informacje uzupełniające albo pozytywne bodźce w czasie tradycyjnego wywiadu.

W projekcie poznańskim i wrocławskim ważną rolę odgrywają fotografie. Badani w projekcie „DE-RE-BORD” mieszkańcy pogranicza zostali poproszeni o robienie zdjęć, które nie tylko pomagały tworzyć mapę ich aktywności (co było powiązane $z$ aplikacją geolokalizacyjną), ale również miały dostarczyć badaczom wiedzę na temat przejawów re/deborderyzacji (badani zgłaszali problemy ze zrobieniem zdjęć, szczególnie w odniesieniu do przejawów deborderingu, czyli podania namacalnych przykładów zamazywania się granicy). Jednakowoż samo wykonywanie zdjęć powodowało również 
u samych respondentów wzbudzenie dodatkowej refleksyjności na temat granicy, co z kolei sprawiało, że wtedy łatwiej się na ten temat rozmawiało. Zatem za istotną z punktu widzenia projektów włączających analizę zdjęć należy uznać kwestię medium zdjęć kto wytwarza treści, z jakiego powodu/dla jakiego celu, w jaki sposób docierają one do badacza. W badaniu narracji w miastach podzielonych jednym z elementów pozwalających je odtworzyć miało być badanie szaty informacyjnej miasta i w tym celu członkinie zespołu tworzyły fotograficzną dokumentację inwentaryzującą komunikaty w miejskich przestrzeniach miast podzielonych. Ale już czas pandemii (który ograniczył wyjazdy badawcze), wywołujący również niecodzienne perturbacje na granicach administracyjnych kraju, skłonił nas do skorzystania $z$ fotografii rejestrujących komunikaty ulotne pojawiające się w badanych miastach, które były dystrybuowane w mediach społecznościowych oraz internetowych wydaniach gazet. Zatem nawet jeśli - zgadzając się z propozycją Katarzyny Kajdanek - nie potraktujemy sytuacji pandemicznej jako czynnika 'wywracającego' projekt, a raczej go krystalizujący, to jednak te nowe okoliczności mogą wymagać modyfikacji metodologicznych i większej otwartości - choćby na fotografie wytwarzane poza środowiskiem projektowym.

\section{Pogranicze „migotliwe”: pomiędzy badaniem procesu a badaniem momentów?}

Wspominana sytuacja pandemiczna wiąże się jeszcze z innym pytaniem: czy badać proces czy moment? Czy skupiać się analizach długiego trwania czy raczej na wydarzeniach mających miejsce w danym momencie? Zdaniem Macieja Kowalewskiego większe uzasadnienie współcześnie może mieć kierowanie się w stronę badań pogranicza „migotliwego” - badaniach momentów zakotwiczonych w rzeczywistości dziejącej się „tu i teraz". Jego zdaniem może być to rozwiązanie dla sytuacji, w których nagle pojawiające się zmiany - jak na przykład przywrócenie kontroli granicznych - zmieniają charakter pogranicza i do pewnego stopnia „obcinają” jego długą historię trwania. Pandemia i wiążący się z nią powrót granicy jako realnej, fizycznej bariery, rzeczywiście dobrze ilustruje takie zjawisko. Granica w miastach podzielonych na przestrzeni lat stała się właściwie niezauważalna, a jej codzienne przekraczanie zakotwiczyło się w codziennych doświadczeniach wielu mieszkańców pogranicza (Dolińska i in. 2018). Jej nagłe pojawienie się ujawniło, jak dalece znormalizowana została sytuacja otwartej granicy, a jednocześnie jak szybko ta sytuacja może ulec zmianie. W przypadku analizowanych w projekcie miast podzielonych (Cieszyn i Czeski Cieszyn oraz Słubice i Frankfurt nad Odrą) zamknięcie granic znacząco wpłynęło na sytuację pracowników transgranicznych (niemogących początkowo kontynuować pracy ze względu na wymóg przechodzenia kwarantanny przy każdorazowym przekraczaniu granicy), uczniów, przedsiębiorców, jak i rodzin zamieszkujących po obu stronach granicy. W związku z tym na pograniczu mogliśmy obserwować różne reakcje na granicę: od performatywnych inicjatyw wyrażających tęsknotę za sąsiadem, przez oficjalne apele do władz centralnych, po akcje 
protestacyjne zwracające uwagę na pułapkę, w której znaleźli się mieszkańcy pogranicza (Dolińska i Makaro 2020). Sytuacja stała się też przyczynkiem do lokalnych badań i opracowań, mających na celu zdiagnozowanie społeczno-ekonomicznych konsekwencji dla mieszkańców i całego regionu, oraz zaproponowanie strategii na wypadek kolejnych tego typu kryzysów (Kasperek i Olszewski 2020; Olszewski 2020).

Pandemia i wiążące się z nią reborderyzacyjne decyzje polityczne stały się istotnym tłem zarówno dla samych mieszkańców pogranicza,jak i dla badaczy przyglądających się procesom zachodzącym na pograniczach. $Z$ pewnością jako badacze i badaczki nie jesteśmy w stanie „zamazać” oddziaływania pandemii na dziejące się już badania, ale jesteśmy w stanie uelastycznić się i ukierunkować się na zbadanie jednego z bardzo ważnych historycznie momentów „powrotu granicy” i obserwować jego konsekwencje. Możemy spojrzeć na pandemię, jak mówi Katarzyna Kajdanek, jako zjawisko wpisujące się w cykl wydarzeń, podczas których granica czasami się zamazuje, a czasami jest odtwarzana. Zależy nam bowiem przede wszystkim na jak najlepszym opisaniu i wyjaśnieniu rzeczywistości społecznej, a nie potwierdzeniu naszych założeń o tym, jaka ta rzeczywistość jest. Wydaje się, że najważniejsze w badaniach są tutaj: elastyczność i otwartość na zmianę oraz czujność i refleksyjność, jeśli chodzi o interpretację gromadzonego materiału badawczego. Dla zrozumienia procesów, dziejących się w określonych momentach konieczna jest wiedza o przeszłych wydarzeniach. Bez odniesienia się do procesu „zanikania” granicy i wpływu wejścia Polski i Czech do strefy Schengen w 2007 roku nie bylibyśmy w stanie zrozumieć reakcji miast podzielonych na ponowne i nagłe pojawienie się kontroli granicznej. Przykładem ilustrującym badanie „momentu” w odniesieniu do historii są badania Radosława Zenderowskiego, który skupia się na analizie dyskursu wokół obchodów setnej rocznicy podzielenia miasta Cieszyna, a dokładniej wokół słupa granicznego, jaki został postawiony w Czeskim Cieszynie w ramach tych obchodów. Bez znajomości historii polsko-czeskich relacji trudno byłoby zrozumieć ten moment, jak i wypowiedzi przedstawicieli obu miast, które zostały zebrane w materiale badawczym.

Warto też zwrócić uwagę, że to właśnie pandemia wydaje się w pełni unaoczniać fakt, że w badaniach należy uwzględniać bardzo różne konteksty, jakie mogą się pojawić i jakie mogą całkowicie zmienić sytuację polityczną. Granice mogą być (re)konstruowane i dekonstruowane nie tylko w wymiarze społeczno-kulturowym, ale mogą też pojawiać się fizycznie. Trzeba mieć też świadomość różnych aktorów społecznych doświadczających granicy. Specyfiką pandemicznego zamknięcia granic jest fakt, że strategia ta została zastosowana przez większość państw i dotknęła obywateli Unii Europejskiej. Jest to jednak jeden z momentów reborderyzacyjnych, które są obserwowane i doświadczane w ciągu ostatnich lat, między innymi przez migrantów spoza UE, w tym uchodźców. Takie szersze społeczno-polityczne konteksty również powinny być uwzględniane przez badaczy i badaczki.

Wydaje się, że odpowiedzią na dylemat pomiędzy badaniem długiego procesu a badaniem momentów jest łączenie obu tych perspektyw - bycie czujnym 
obserwatorem życia społecznego, „chwytającym” dziejące się zmiany, ale ze świadomością przeszłości i różnych poziomów kontekstu. Należy tutaj uwzględniać zarówno konteksty bezpośrednio towarzyszące danym momentom, jak i te poprzedzające je. Bez ich znajomości tracimy bowiem - jako badacze i badaczki - ważną wiedzę niezbędną dla zrozumienia i zinterpretowania tego, co obserwujemy.

\section{Zamiast podsumowania - wyzwania badania granic i pograniczy}

Badanie zjawisk zachodzących na pograniczach stanowi wyzwanie dla naukowców różnych dyscyplin. Po pierwsze granice i przestrzenie pograniczy znajdują się w dynamicznym procesie przemian, na które wpływ mają różni aktorzy społeczni. Globalne powiązania współczesnego świata sprawiają, że wydarzenia w jednej części globu bezpośrednio oddziałują na dyskursy, narracje i działania podmiotów w drugiej części świata. Granice nie są już postrzegane jedynie jako statyczne linie na mapach świata, oddzielające suwerenne państwa, ale jako mobilne i kompleksowe zjawiska, które badacz może „uchwycić" tu i teraz, co wymaga jego ciągłej uwagi i refleksyjności. Jest o tyle trudniejsze w przypadku analizowania miast podzielonych, że na procesy okołograniczne nakładają się procesy wynikające $z$ przemian miast. $Z$ drugiej strony nie możemy zapominać, że przestrzenie pogranicza kształtowały się przez wiele lat i kluczem do zrozumienia współczesnych procesów de-/re-borderingu jest wiedza historyczna - kiedy granica została ustanowiona? Jakie stosunki panowały między mieszkańcami pogranicza? Jak wyglądały relacje pomiędzy częściami miast podzielonych i przez jakie procesy były kształtowane? Czy wokół granicy toczyły się spory? To właśnie często te granice niewidoczne, określane w literaturze jako fantomowe (Hirschhausen 2020), niezaznaczone na mapach, ale wciąż manifestujące się w mentalności i praktykach mieszkańców czy w animozjach historycznych, są najtrudniejsze do zbadania.

Po drugie, kompleksowość granic wymaga podejścia interdyscyplinarnego. Jak podkreśla Christian Wille (2021), w studiach nad granicami zaszły w ostatnich latach trzy zwroty, dla których nadrzędną stała się wykładnia granic jako praktyk społecznych. Pierwszy z nich, zwrot procesualny (processual shift) oznaczał odejście od rozumienia granicy jako stałej i sztywnej linii podziału w kierunku interpretacji granicy jako produktu społecznych procesów konstrukcji. Drugi zwrot, nazwany multiplikacyjnym (multiplicity shift), należy rozumieć jako kontynuację i rozszerzenie zwrotu procesualnego. Granice jako wytwory społeczne stają się coraz bardziej zróżnicowane, i wielowymiarowe, muszą być wyjaśniane z różnych perspektyw. Ważne jest zatem nie tylko, jak są (re) produkowane, ale przez kogo i wobec kogo, a także w imię czyich interesów. Trzeci zwrot, kompleksowy (complexity shift), podkreśla, że (de)konstruowanie granic jest dynamicznym procesem wynikającym ze złożonych relacji między wiedzą, dyskursami, działaniami, obiektami i ciałami, które wytwarzają i są wytwarzane przez granice, są powiązane w różnoraki sposób i powinny być analizowane w ich społecznym, materialnym, przestrzennym i czasowym wymiarze. 
Podsumowując, można stwierdzić, że przed badaczami oraz badaczkami granic i pograniczy stoi wiele wyzwań. Wynikają one $z$ wielowymiarowości, wieloznaczności i kompleksowości granic. Należy tutaj pamiętać, że badacze nie są jedynie uważnymi obserwatorami, ale jako twórcy wiedzy biorą czynny udział w konstruowaniu tekstur granic.

Bardzo dziękujemy badaczkom i badaczom, którzy zgodzili się wziąć udział w organizowanych przez nas warsztatach: dr. hab. Krzysztofowi Bierwiaczonkowi, prof. UŚ; dr. hab. Marcinowi Dębickiemu, prof. UWr; śp. dr. hab. Jerzemu Kaczmarkowi, prof. UAM; dr hab. Katarzynie Kajdanek, prof. UWr; dr. hab. Maciejowi Kowalewskiemu, prof. US; dr. hab. Piotrowi Kulasowi, dr. Łukaszowi Rogowskiemu oraz prof. dr. hab. Radosławowi Zenderowskiemu.

\section{Bibliografia}

Bauman Z. 1996. Tourists and vagabonds: heroes and victims of postmodernity, Reihe Politikwissenschaft /Institut für Höhere Studien, Abt. Politikwissenschaft, 30. Wien: Institut für Höhere Studien (IHS), 1-15. https://nbn-resolving.org/urn:nbn:de:0168-ssoar-266870.

Beck U. i Grande U. 2006. Europa kosmopolityczna Spoteczeństwo i polityka w drugiej nowoczesności. Warszawa: Scholar.

Bierwiaczonek K., Dymnicka M., Kajdanek K. i Nawrocki, T. 2017. Miasto Przestrzeń Tożsamość. Studium trzech miast Gdañsk, Gliwice, Wroctaw. Warszawa: Scholar.

Brambilla Ch. 2015. Exploring the critical potential of the borderscapes concept. Geopolitics 20(1), 14-34.

Dolińska K. i Makaro J. 2020. O rodzeniu się wielokulturowości z transgraniczem w tle. $\mathrm{Na}$ przykładzie pandemii COVID-19 (i jej skutków) w miastach podzielonych. Przegląd Zachodni 4/2020, 225-243.

Dolińska K., Makaro J. i Niedźwiecka-Iwańczak N. 2018. Cud pogranicza? Zgorzelczanie, gubinianie i stubiczanie o życiu w miastach podzielonych. Kraków: Zakład Wydawniczy Nomos.

Gerst D., Klessmann M. i Krämer, H. (eds.) 2021. Grenzforscbung. Handbuch für Wissenschaft und Studium. Baden-Baden: Nomos.

Hirschhausen von B. 2020. Granice fantomowe. [W:] E. Opiłowska, M. Dębicki, K. Dolińska, J. Kajta, Z. Kurcz, J. Makaro i N. Niedźwiecka-Iwańczak (red.), Studia nad granicami i pograniczami. Leksykon. Warszawa: Scholar, 144-157.

Kasperek B. i Olszewski M. 2020. Spoteczno-gospodarcze skutki zamknięcia polsko-czeskiej granicy dla pracowników transgranicznych w Euroregionie Ślask Cieszyñski w zwiqzku z pandemiq COVID-19, http://www.olza.pl/p1/pliki-do-pobrania/, 30.04.2021.

Kłopot S. 2019. Wrocławska socjologia miasta w latach 2009-2019. [W:] E. Wojtaś i J. Wojtaś (red.) Wroctawskie reminiscencje socjologiczne. Kontynuacje. Wrocław: D1 CUBA, 125-135. 
Kurcz Z. 2020. Socjologia pogranicza. [W:] E. Opiłowska, M. Dębicki, K. Dolińska, J. Kajta, Z. Kurcz, J. Makaro i N. Niedźwiecka-Iwańczak (red.), Studia nad granicami i pograniczami. Leksykon. Warszawa: Scholar, 389-399.

Makaro J. 2020. Miasta podzielone. [W:] E. Opiłowska, M. Dębicki, K. Dolińska, J. Kajta, Z. Kurcz, J. Makaro i N. Niedźwiecka-Iwańczak (red.), Studia nad granicami i pograniczami. Leksykon. Warszawa: Scholar, 218-229.

Niedźwiecka-Iwańczak N. 2020. Pogranicze. [W:] E. Opiłowska, M. Dębicki, K. Dolińska, J. Kajta, Z. Kurcz, J. Makaro i N. Niedźwiecka-Iwańczak (red.), Studia nad granicami i pograniczami. Leksykon. Warszawa: Scholar, 283-294.

Ohmae K. 2008. The End of the Nation State. [W:] F.J. Lechner i J. Boli (eds.), The Globalization Reader. Malden: Blackwell Publishing, 223-227.

Olszewski M. 2020. Model Komunikacji w Sytuacjach Kryzysowych Model Krizové Komunikace, http://www.olza.pl/pl/dzialalnosc-statutowa/publikacje/16/, 30.04.2021.

Opilowska E. 2021. The Covid-19 crisis: the end of a borderless Europe? European Societies 23(sup1), 589-600. DOI: 10.1080/14616696.2020.1833065.

Paasi, A. 2009. Bounded spaces in a 'borderless world': border studies, power and the anatomy of territory. Journal of Power 2 (2), 213-234. DOI: 10.1080/17540290903064275.

Raczyk A. 2020. Delimitacja obszarów pograniczy. [W:] E. Opiłowska, M. Dębicki, K. Dolińska, J. Kajta, Z. Kurcz, J. Makaro i N. Niedźwiecka-Iwańczak (red.), Studia nad granicami i pograniczami. Leksykon. Warszawa: Scholar, 56-63.

Słomczyński K. M. 2014. Empiryczne analizy porównawcze w badaniach pogranicza. [W:] M. Zielińska, B. Trzop (red.), Transgraniczność w perspektywie socjologicznej. Pogranicza i centra wspótczesnej Europy. Zielona Góra: Lubuskie Towarzystwo Naukowe, 87-99.

Van Houtum H. i van Naerssen T. 2002. Bordering, Ordering and Othering. Tijdschrift voor Economische en Sociale Geografie 93(2), 125-136.

Wassenberg B. i Reitel B. (red.) 2020. Critical Dictionary of Borders, Cross-Border Cooperation and European Integration. Bruksela: Peter Lang.

Wille C. i Weber F. 2020. Analyzing border geographies in times of Covid-19. [W:] G. Mein and J. Pause (esd.) Self and Society in the Corona Crisis. Perspectives from the Humanities and Social Sciences. Melusina Press.

Wille C. 2021. Vom processual shift zum complexity shift: Aktuelle analytische Trends der Grenzforschung. [W:] D. Gerst, M. Klessmann i H. Krämer (eds.), Grenzforscbung. Handbuch für Wissenschaft und Studium. Baden-Baden: Nomos, 106-120.

Wilson T. M. i Donnan H. (eds.) 2012. A Companion to Border Studies. Chichester: Wiley-Blackwell.

\section{Materiały}

Bierwiaczonek K. 2020. Miasto jako struktura spoteczno-przestrzenna-przestrzenie publiczne i ich znaczenie, narracje miejskie, tożsamośc miasta i jego mieszkańców. Prezentacja wygłoszona 
podczas warsztatów „Narracje i imaginacje w miastach podzielonych: między socjologią miasta a socjologią pogranicza".

Kaczmarek J. i Rogowski Ł. 2020. Projekt "DE-RE-BORD. Socio-spatial transformations in German-Polish "interstices". Practices of debordering and rebordering". Wyzwania badania terenów przygranicznych $i$ miast podzielonych, metodologia badan wizualnych $i$ mobilnych. Prezentacja wygłoszona podczas warsztatów „Narracje i imaginacje w miastach podzielonych: między socjologią miasta a socjologią pogranicza”.

Kulas P. 2020. Koncepcja narracji jako kategorii teoretycznej i empirycznej. Socjologiczne ujecie narracji w kontekśsie innych dyscyplin. Prezentacja wygłoszona podczas warsztatów „Narracje i imaginacje w miastach podzielonych: między socjologią miasta a socjologią pogranicza”.

Zenderowski R. 2020. Nikdo nic nevi, czyli krótka historia czesko-cieszyńskiego stupa granicznego. Prezentacja wygłoszona podczas warsztatów „Narracje i imaginacje w miastach podzielonych: między socjologią miasta a socjologią pogranicza”.

Autorki:

dr hab. Kamilla Dolińska

e-mail: kamilla.dolinska@uwr.edu.pl

dr Justyna Kajta:

e-mail: jkajta@swps.edu.pl

dr hab. Julita Makaro, prof. UWr

e-mail: julita.makaro@uwr.edu.pl

dr hab. Natalia Niedźwiecka-Iwańczak, e-mail: natalia.niedzwiecka-iwanczak@uwr.edu.pl

dr hab. Elżbieta Opiłowska, prof. UWr, e-mail: elzbieta.opilowska@uwr.edu.pl

Adres do korespondencji z Autorkami:

OBROP, Instytut Socjologii, Uniwersytet Wrocławski

ul. Koszarowa 3, 51-149 Wrocław 